\title{
Depicting a Prayer before the Battle: On the Reader's Marginalia Drawing in the Old Rus' Manuscript from the British Library
}

\author{
Fedor Veselov \\ $\mathrm{PhD}$, Assistant Professor, Institute of History of the St. Petersburg State \\ University, St. Petersburg, Russia \\ veselovfedor@gmail.com
}

\begin{abstract}
In the note, the author focuses on the additional drawing made by an unknown reader on the miniature of the Old Rus' illuminated manuscript of the Tale of the Route of Mamai. The drawing depicts the image of the Mandylion over one of the key scenes of the Tale: Dmitry Donskoy receiving the blessing and prosphoron from St Sergius of Radonezh. The author examines both, the text, that is illustrated, which cites the monastic rite of Panagia, and the symbolism of the image of the Holy Saviour Not Made by Hands, to conclude whether the addition was accidental or not.
\end{abstract}

\section{Keywords}

The Mandylion - the rite of the Panagia - illuminated manuscripts - the Tale of the Route of Mamai - the Battle of Kulikovo - the British library

\section{Introduction}

Among the many excellent manuscripts in the collection of Sir Henry Yates Thompson in the British Library, there is a curious work originating from Russia. On the library website the MS is dated the $17^{\text {th }}$ century, ${ }^{1}$ but a

1 The digitised copy of the MS is accessible on the web-site of the British Library: <http://www. bl.uk/manuscripts/FullDisplay.aspx?ref=Yates_Thompson_MS_51>. 
recent study of the paper watermarks provides a more accurate dating, the 165 os. $^{2}$

The MS is written on the 'in folio' paper (dimensions: $290 \times 185 \mathrm{~mm}$ ) and bound between two wooden boards with a leather spine. Forty-eight folios of the codex contain the Tale of the Rout of Mamai (hereafter the Tale), illustrated with sixty-four coloured miniatures. This British Library MS was introduced into academic use by Elizabeth Hill at the 4th International Congress of Slavists held in Moscow in 1958. Hill's paper led O. Podobedova and D. Likhachev to the conclusion that the Ms had been copied from an illuminated protograph of the 16 th or even the $15^{\text {th }}$ century. ${ }^{3}$

The Tale is an Old Russian literary work, containing a detailed story of the Battle of Kulikovo of 1380, when the Russian warriors led by Grand Prince Dmitry Ivanovich defeated the army of the Golden Horde's warlord Mamai. There are several points of view in historiography concerning the date when the work was composed. However, a number of anachronisms in the text with regard to the toponymy (e.g., the mention of the Konstantino-Eleninskiye Kremlin gate, which appeared only in the second half of the 15th century) and material culture (e.g., the mention of 'yalovtsi' - special crests on helmets, which appeared at the end of the 15th century), the influence of later literary works and references to later administrative documents show that the Tale appeared not earlier than the turn of the 16th century. The oldest copy of the Tale (Russian National Library, O.IV.22) dates back to the 153 os. ${ }^{4}$

The Tale was the most popular literary work in Old Rus' among all other literary sources, providing a story of the Battle of Kulikovo. Today there are more than one and a half hundred known handwritten copies of it; however, only nine of them are illuminated. Eight of the manuscripts (including the British one) contain the same literary recension of the Tale, while the ninth is included in the Illuminated Chronicle of the 16th century and is often considered separately. 5 Two of the eight illuminated copies of the Tale are included in

2 Ф. Веселов, “Рукопись Chester Beatty W.151 [F. Veselov, Manuscript Chester Beatty W.151]," in: Александрия сербскал. Дублинский список [Serbian Alexander Romance. The Dublin copy], St Petersburg, 2018, pp. 11-23.

3 IV международный съезд славистов. Материалы дискуссии [The 4th International congress of Slavists. Proceedings of discussions], Vol.1, Moscow, 1962, pp. 165-166.

4 Б. Клосс, “Сказание о Мамаевом побоище [B. Kloss, The Tale of the Route of Mamai]," in: Избранные труды [Selected works], Vol. II, Moscow, 2001, pp. 331-348; bibliography on the question: А. Петров, Сказание о Мамаевом побоище как исторический источник [A. Petrov, The Tale of the Route of Mamai as the historical source], PhD thesis, Moscow, 1998.

5 А. Амосов, “Сказание о Мамаевом побоище в Лицевом своде Ивана Грозного [А. Amosov, The Tale of the Route of Mamai in the Illuminated Chronicle of Ivan the Terrible]," TODRL, 34 (1979), pp. 58-59. 
similar codices (the State Historical Museum (hereafter SHM), Barsov coll., 1798 and the Russian State Library (hereafter RSL), Museum coll., 3155), containing also the Serbian version of the Alexander Romance (hereafter the Romance), another very popular literary work of the late Medieval and Early Modern Russia. The Tale from the British Library was also a part of a larger codex: old Cyrillic numeration of its folios starts only from number 156, which means that the Tale was preceded by another large text. ${ }^{6}$ Lev Dmitriev, one of the first researchers of the work, assumed that the Tale was preceded by the Romance. ${ }^{7}$ This hypothesis was confirmed when A Union Catalogue of Cyrillic Manuscripts in British and Irish Collections was published: indeed, the manuscript, containing the Romance, which is now kept in the Chester Beatty Library, Dublin (shelf mark W.151), ${ }^{8}$ is identical with the British Library manuscript in terms of paper, handwriting and the style of illustrations. Most importantly, both codices have continuous foliation.

The two Russian codices mentioned above (sHM, Barsov coll., 1798 and RSL, Museum coll., 3155), containing the Tale and the Romance, are written on the 'in folio' paper by professional scribes and lavishly decorated by the artists. The manuscript from the Historical Museum originates from the library of Afanasiy, the first archbishop of the Kholmogory diocese, established in 1682. At the time, the only way for the 17 th century Russia to access the sea was from the north, so the newly organised diocese was strategically important and was governed by an intelligent and erudite archpriest. The manuscript was produced during the years of Afanasiy's service, when he started building the book collection that after his death became the core of the Kholmogory (later Archangelsk) Seminary Library, and, presumably, the creation of the book was ordered by him personally. ${ }^{9}$ No signs of provenance can be found on the folios of the badly preserved manuscript from the State Library; however, the same folio

6 First mentioned by E. Hill: E. Hill, British Museum Illuminated Manuscript of an Early Russian Literary Work: An Encomium to the Grand Prince Dimitri Ivanovich and to his Brother Prince Vladimir Andreyevich, the Tale of the Battle of the Don in the Year 6889. IV International Congress of Slavists, Cambridge, 1958, p. 2.

7 Л. Дмитриев, “Миниатюры 'Сказания о Мамаевом побоище' [L. Dmitriev, Miniatures of the 'Tale of the Route of Mamai']," тоDrL, 22 (1966), p. 256; Л. Дмитриев, “Лондонский лицевой список 'Сказания о Мамаевом побоище' [L. Dmitriev, London illuminated copy of the 'Tale of the Route of Mamai']," TODRL, 28 (1974), pp. 156-157.

8 R. Cleminson, A Union Catalogue of Cyrillic Manuscripts in British and Irish Collections, The Anne Pennington Catalogue, London, 1988, pp. 176-178.

9 Ю. Грибов, "Холмогорские иллюстрированные апокалипсисы конца XVI - первой половины XVII вв.: вопросы атрибуции [Yu. Gribov, Cholmogory illuminated Books of Revelations of the end of 16 th - first half of the $17^{\text {th }}$ centuries: problems in attribution]," Хризограф [Chrysograph], 1 (2003), p. 209. 
format, the calligraphic hand and the quality of the illustrations suggest that it was also made to order. If compared in terms of text and miniature cycles, both of these manuscripts are very close to the British Library copy. The British Library manuscript is the oldest surviving copy of such illuminated literary codices, as the Historical Museum and the State library manuscripts were produced only at the end of the 17th century.

It is notable that the British Library copy remained unfinished: its miniatures were coloured more than one and a half centuries later. Paper with 'Pro Patria' watermarks, dating back to the end of the 18th century, was at some point used as material for glued over repair patches. In places where these patches cover the miniatures, the underlying drawings are not coloured (e.g., on f. 21v). Crude and in many cases incorrect colouring of the miniatures also seems to suggest that they were coloured not by the hand of the codex's principal artist. However, the colouring of the miniatures was not the only addition to the manuscript by its readers: some details of the drawings were also added later. In this paper, I am going to discuss whether these additions were accidental or not, given the high value of any handwritten book in all times. If the additions were not accidental, what was the reason for their appearance?

The most significant additional drawing is placed on the miniature on f. 36 (fig. 1). It depicts the icon of the Holy Saviour Not Made by Hands (also known as the Holy Mandylion), while additional drawings on other miniatures represent small details, such as lances and bridles added to the illustrations (e.g., on f. 45 v etc.).

The miniature on $\mathrm{f} .36$ depicts the arrival of messengers from St Sergius of Radonezh, who sent Communion bread and his blessing to Grand Prince Dmitry and all Rus' warriors before the Battle of Kulikovo. The icon of the Holy Saviour Not Made by Hands is placed above the whole scene in the illustration. The sketchy lines of the icon's drawing, different from the professional hand of the main illustrator of the codex, a different ink colour and a different width of the feather pen attest to the fact that this was an addition to the miniature, which had not been made by the main illustrator of the codex. In the place where the icon is drawn, the paper is repaired with a patch. This patch partially covers the outline of the drawing, but it does not cover the colouring, which means that the drawing was made before the repair work on the codex in the late 18 th century. 


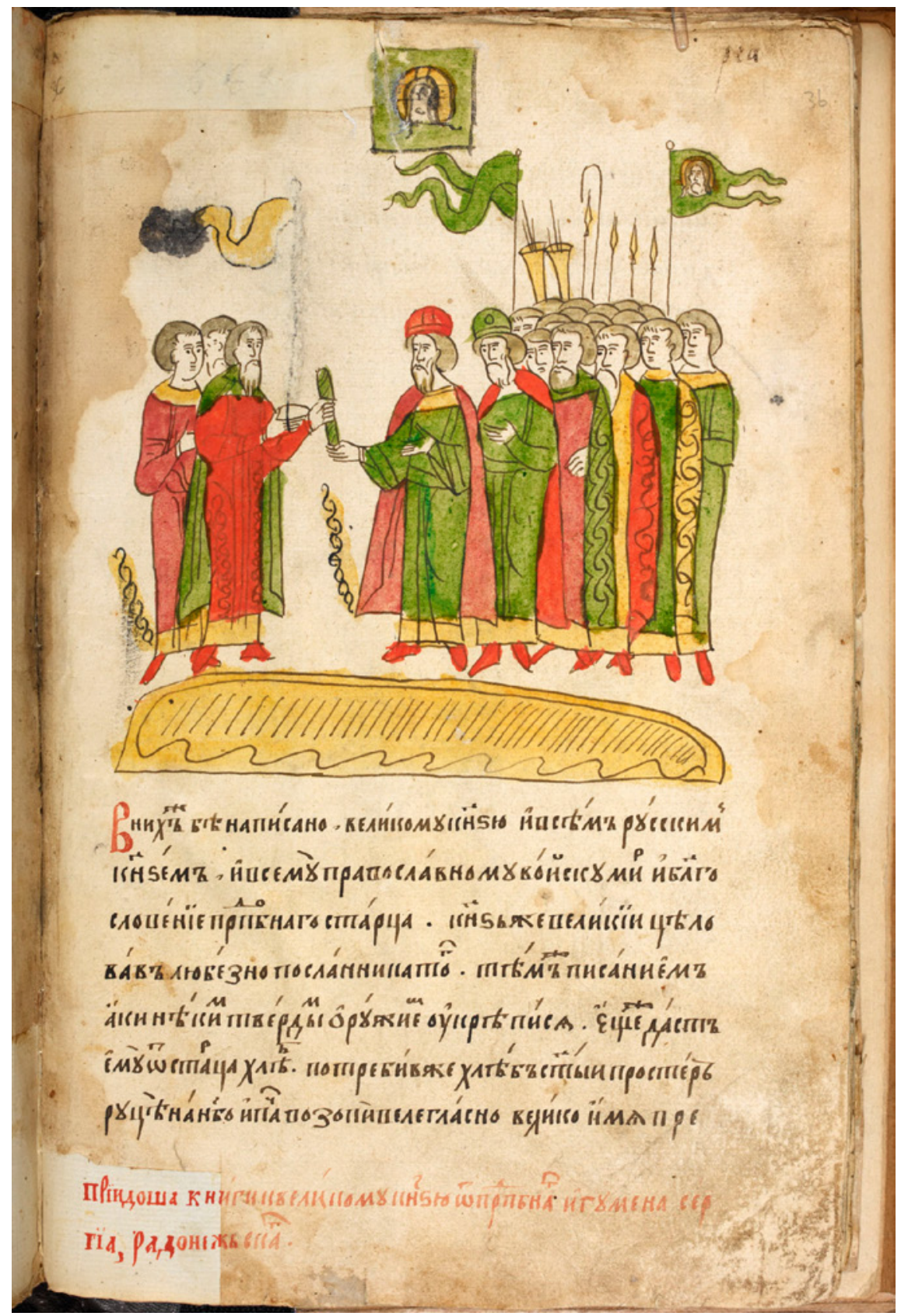

FIGURE 1 The Tale of the Mamai Route, London, the British Library, Yates Thomson Ms 51, fol. $36 r($ British Library Board 
Such drawings added to the miniatures of Old Rus' manuscripts were not unusual. One will find such additions even in Old Rus' illuminated chronicles, e.g. the additional drawings on the miniatures of the famous Radzivillovskaya Chronicle of the early $15^{\text {th }}$ century. At the same time, these additions were meaningful for their authors. ${ }^{10}$ Moreover, it is known that in some cases the added drawings could become 'legalised' through their replication during the copying of manuscript miniatures. In one of the 18th-century illuminated manuscripts of the Tale (sHM, Museyskaya coll., 2596), some reader added halos to the images of Metropolitan Cyprian, who became a locally venerated saint only at the beginning of the 19th century. ${ }^{11}$ Ivan Blinov, who copied the MS, made these additions 'canonical' by including them in his 1894 copy (RSL, Pryanishnikov coll., 203). ${ }^{12}$

That means that the drawing of an icon with one of the most venerated iconographies above the illustration on f. 36 of the British Library's copy of the Tale could have had special importance for its unknown author. Besides, as already pointed above, the image of the Holy Saviour Not Made by Hands is the only meaningful additional drawing on the miniatures of the Ms. The reasons for the appearance of this drawing, in our opinion, could be found either inside the text that it illustrates or in the iconographical meaning of the added image, which makes it important to examine both.

\section{3}

\section{The Text as the Source of the Additional Drawing}

First of all, it seems logical to refer to the text illustrated by the miniature. The title of the miniature inscribed in red ink at the bottom of the folio does not give us much information: 'The books came to Grand Prince from St Sergius of Radonezh'. At the same time, the text of the Tale, accompanying the illustration on ff. $35 \mathrm{v}-36 \mathrm{v}$, says:

10 Seе: A. Толочко, “Пририсовки зверей к миниатюрам Радзивилловской летописи и проблема происхождения рукописи [A. Tolochko, Additional drawings of beasts on the miniatures of the Radzivillov Chronicle and the problem of the manuscript's origins]", Ruthenica, 4 (2005), pp. 62-84.

11 Е. Голубинский, История канонизации святых в Русской церкви [E. Golubinskiy, History of the canonisation of Saints in Russian church], Moscow, 1903, pp. 191-194.

12 Towards the question of the author of the сору, seе: Ф. Веселов, Лицевые списки Сказания о Мамаевом побоище ХVII-ХIX вв. в музейных и библиотечных собраниях [F. Veselov, Illuminated copies of the Tale of the Route of Mamai of the 17th-19th centuries in Museums and Libraries collections], PhD Thesis, St. Petersburg, 2017, pp. 222-226. 
at the time [messengers] brought to him books from Saint Hegumen Sergius, in which was written the blessing from the venerable elder $<\ldots>$ and they gave to him [Grand Prince] the holy bread (i.e. 'Communion bread') from the elder. And he ate the holy bread and raised his hands to heavens and cried loudly: "Great is the name of the Holy Trinity! All Holy Mother of God, help us with your prayers [and at the prayers] of hegumen Sergius!". ${ }^{13}$

Indeed, this miniature, unlike the miniatures on the same subject in other illuminated copies of the Tale, shows the messenger from Sergius of Radonezh with a prosphoron in his hand. The iconography of the prosphoron is definitely the same as on the miniature in the Illuminated Chronicle (2nd Osterman Vol., f.85, Library of the Russian Academy of Science, 31.7.30-2).

The Prince's prayer, included in the text, word-for-word repeats the prayer included in the Order of the Holy Mount if it happens for some monk to leave the monastery for some reasons: [if in absence of a priest] '... [you should] raise the holy bread, saying: "Great is the name of the Holy Trinity! All Holy Mother of God, help us! Jesus Christ our Lord, save us at Her prayers!"'. This rule is included in some Slavonic Typicons, influenced by the Typicons of the Holy Mount Athos at the time of changing over from the Studion to the Jerusalem Typicon in the

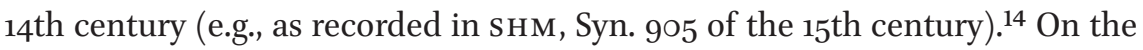
one hand, this rule is not included in the oldest 14th-century Russian manuscripts of the Jerusalem Typicon (see: SHM, Syn. 328, 329). On the other hand, this rule was repeatedly mentioned up until the 17th century, e.g., in the first printed Typicon of 1610 (hereafter the Typicon of 1610). ${ }^{15}$ However, it was already excluded from the Typicon reformed by Patriarch Joachim in 1682. Bearing in mind that the text of the older recension of the Tale should be dated not earlier than the beginning of the 16th century, it can be assumed that the author was familiar with this Rule of the Holy Mount Athos, which he put into the mouth of Grand Prince.

The Rule of the Holy Mount mentioned above is a special case of serving the rite of the Lifting of the Panagia. The rite itself, according to the Jerusalem Typicon, involves a prosphoron solemnly blessed in honour of the Mother of God (i.e. the Panagia, one of the prosphora, which plays a significant role in the

13 The text of the examined manuscript is published: Памятники Куликовского цикла [Literary works of the 'Kulikovskiy cycle'], St Petersburg, 1998, pp. 137-194.

14 Н. Мансветов, Церковный устав (Типик). Его образование и судьба в греческой и русской церкви [N. Mansvetov, Church canons (Typicon). Its origins and history in Greek and Russian churches], Moscow, 1885, pp. 226-228. 
Preparation of the Holy Eucharist). According to the Typicons of the 14th and 15th centuries mentioned above, after the meal held following the liturgy, 'the deacon or the reader or some of the brothers lift the blessed bread, making a prayer with the hegumen and other brothers: "Great is the Name of the Holy Trinity! All Holy Mother of God, help us! Jesus Christ our Lord, save us at Her prayers!"' (sh M, Syn. 328 f. 40v., Syn. 329 f. 37 the Typicon of 1610, ff. 116v.-117). At the same time, the text of the Tale stresses that the Grand Prince 'cried out', which bears more similarity to the ceremony, held in the monastery. This characteristic feature is recorded in the Typicons: 'Crying out, "Great is the name of the Holy Trinity!'”. Thus, one can conclude that the unknown reader, when depicting the Mandylion, tried to emphasize the connection of the story presented in the miniature with the monastic Rite of Panagia, held in the monastery refectory in front of the icons. Moreover, the episode of consuming the blessed bread after the liturgy appears in the Tale two more times (making it three altogether), and all the times in the monastery of St Sergius: before and after the battle (f. 12-12v. and f. 48v.).

\section{The Meaning of the Iconography of the Holy Saviour Not Made by Hands}

If the unknown reader was inspired by the similarity in the Grand Prince's prayer to the Typicon, it would be reasonable to ask the following question: Why is it the Holy Saviour Not Made by Hands that was depicted? Was it not more logical to depict the image of the Holy Trinity or the Mother of God? On the one hand, the icon of the Mandylion is the only (sic!) icon appearing on the miniatures of this and other copies of the Tale which are close to it in terms of the text and the cycle of miniatures. It is before the icon of the Holy Saviour that Grand Prince Dmitry is praying when he first hears about Mamai's raid; with his cousin, Prince Vladimir Andreevich, Grand Prince prays before this Holy Image in the Assumption Cathedral prior to the battle, and in St Andronicus Monastery - after the victory. The Holy Saviour Not Made by Hands could be often seen on Rus' battle flags. On the other hand, it would be hard to imagine that the 'editor' of the miniature on $\mathrm{f} .36$ had no other iconographic sources of reference - after all, he lived in the Russian Orthodox world, surrounded by icons.

The reason for this can be found in a very close connection between the image of the Holy Saviour Not Made by Hands and the Battle of Kulikovo, firmly established in the official memory about this episode of Russian history. Apart from its commemoration in literary monuments, such as the Tale 
under discussion, where Grand Prince is praying before the battle in front of the 'Prince's Black Banner with the image of the Holy Saviour,, ${ }^{16}$ this memory can be found even in the items of medieval needlework that appeared soon after the battle, e.g., the embroideredpaten veil ('sindon') of Grand Princess Maria of Tver made in 1389 , from the SHM collection. ${ }^{17}$ It has the image of the Mandylion and the figures of warrior saints, including St Boris and St Gleb, the warrior patrons of the ruling house, and St Dmitry of Thessaloniki and St Prince Vladimir, patron saints of the heroes of the battle: Dmitry Donskoy and his cousin Vladimir of Serpukhov.

The association of this Holy Image with the idea of the protection of Christianity is not surprising: it is recorded in the Tale of the Holy Image of Our Saviour, which appeared in the time of Constantine Porphyrogenitus (ca. 944). It tells a legend about the Holy Mandylion saving the Christians of Edessa from the Persian army of Khosrow I. The moving of the Relic to Constantinople in the mid-1oth century became a 'catalyst' for the popularisation of the image in Byzantine art. In the 11th century, the image of the Mandylion appears in the composition of church frescoes, and soon moves from the diaconicon to the eastern wall behind the altar space and to the eastern wall arch, since the relic itself was placed in a golden vessel below the eastern wall arch in the Chapel of the Virgin of the Pharos in the Great Palace of Constantinople. The system of Byzantine church frescoes placed the Holy Mandylion close to the scene of the Holy Eucharist of the Apostles, thus including it into the iconographic programme of the altar frescoes, illustrating the miracle of the Eucharist. ${ }^{18}$ The placing of the image of the Mandylion on the eastern wall arch was mirrored in the frescoes of Russian churches, ${ }^{19}$ not only of the pre-Mongol period (e.g., the Transfiguration Cathedrals of the Mirozhskiy Monastery in Pskov and the Euphrosyne Monastery in Polotsk of the 12th century), but also of the Moscow Russia period (e.g., the Nativity of the Virgin Church in the Ferapontov Monastery of the early 15 th century).

The central part of the composition of the miniature on $\mathrm{f} .36$ represents the passing of the prosphoron from one of the most venerable saints to one of the

16 Памятники... р. 174.

17 Государственный исторический музей. Альбом [State Historical museum. Album], Moscow, 2006, pp. 390-391.

Ш. Герстель, “Чудотворный Мандилион [Sh. Gerstel', The Miraculous Mandylion],” in: Чудотворная иконак в Византии и Древней Руси [Wonderworking Icon in Byzantine and Old Rus'], Moscow, 1996, pp. 76-87.

М. Лидов, “О константинопольском прототипе царского храма [M. Lidov, Towards Constantinople prototype of the Tsar cathedral]," in: Царский храм. Благовещанский собор Московского кремля в истории русской культуры [The tsar cathedral. Assumption cathedral of the Moscow Kremlin in history of Russian culture], Moscow, 2008, pp. 27-28. 
most honoured warlords (i.e., the protectors of the Holy Faith) of Medieval Russia. This happens at the moment when the Grand Prince is getting ready 'to drink the cup of martyrdom' for the Holy Orthodox Faith, ${ }^{20}$ which the text of the Tale emphasizes several times. Right after taking the prosphoron and finishing his prayer, the Prince 'took his lance and headed forward from his regiment, desiring to fight himself out of the sadness of his soul for his great grievance..21

This association of Christian warriors, fighting for the Holy Faith, with martyrs has a long tradition in Christian historiography. Sebeos, an Armenian historian of the $7^{\text {th }}$ century, represents the heroes of the Armenian rebellion against the Sassanid rule as warrior saints and martyrs, who had suffered for their faith. The idea of the holy martyrdom of Russian warriors assumes even more significance if one bears in mind the interpretation of the hourly timeline of the Battle of Kulikovo (the 3rd, 6th and gth hours), represented in the Tale as a symbolic reference to the Holy Liturgy. ${ }^{22}$ In this case, the battle itself turns into a symbol of martyrdom and the Holy Eucharist, the idea highlighted throughout the text. For instance, there is an episode in the Tale, describing how during the battle someone from the ambush party has a vision of the crowns of martyrdom, coming down from Heaven to the heads of the Russian warriors, fighting for 'the holy churches and the Christian faith.'23

Thus, the appearance of the icon of the Holy Saviour Not Made by Hands above the scene of the communion of Dmitry Donskoy with the prosphoron before his symbolic martyrdom (according to the Tale, the Grand Prince was found barely alive after the battle) could be explained by the place of the Mandylion in the iconographic system of medieval church frescoes and its expressed significance as a protector of Christians. It is worth noting that this Holy Icon had been represented on the battle flags of the Russian army up until World War I.

\footnotetext{
20 Памятники... р. 176.

21 Ibid. p. 175 .

22 В. Рудаков, “'Дух южный’ и 'Осьмой час' в 'Сказании о Мамаевом побоище' [V. Rudakov, 'Breath from the South' and the 'eighth hour' in the 'Tale of the Route of Mamai']", in: Герменевтика древнерусской литературы [Hеrтепеutics of the Old Rus' literature], 9 (1998), pp. 137-157; В. Кириллин, Таинственная поэтика 'Сказания о Мамаевом побoume' [V. Kirillin, Mysterious poetics of the 'Tale of the Route of Mamai'], Moscow, 2007, pp. 74-75.

Памятники... р. 174, 179.
} 


\section{$5 \quad$ Conclusion}

It seems reasonable to conclude that the appearance of the only significant reader's marginalia drawing on the miniatures of the British copy of the Tale was not accidental. The unknown reader depicted the icon of the Holy Saviour Not Made by Hands (the Mandylion) above the scene of Dmitry Donskoy receiving the blessing and prosphoron from one of the most venerable saints of Medieval Russia. Besides, the text that is illustrated by the miniature cites the monastic rite of Panagia, which was to be served in front of the icons, and the British manuscript is the only one where a prosphoron is depicted. In addition, the use of the Holy Saviour Not Made by Hands is highly symbolic, as this iconographic image in particular had a traditional well-established significance for the memory of the Battle of Kulikovo. The connection between the image of the Holy Saviour and the battle is based on the idea that runs through the whole text of the Tale, namely, the idea of the fight for the Christian faith and the traditional veneration of the Mandylion as the protector of Christianity, known since the time of the miraculous saving of Edessa from the armies of Khosrow I.

\section{Acknowledgement}

The note is based on the study, first presented at the International Conference Liturgy as Practice, Space and Theory in Eastern Christianities, held in Kirillov, 1-4 October, 2019. The study is a part of a larger project, supported by the Russian Scientific foundation Nr. 16-18-10137 'Detection, study and publication of Russian written monuments, stored in the collections of foreign museums, archives and libraries'.

The author would like to express his deepest gratitude to Dr. Jana Howlett for her kindest consultations. 
